\title{
Analisis Pengaruh Komposisi Partikel Ampas Tebu dan Partikel Tempurung Kelapa terhadap Sifat Fisis dan Mekanis Komposit Papan Partikel Perekat Resin Epoksi
}

\author{
Widi Mulia Nasution*, Mora \\ Laboratorium Fisika Material, Jurusan Fisika \\ Fakultas Matematika dan Ilmu Pengetahuan Alam Universitas Andalas \\ Kampus UNAND Limau Manis, Padang, 25163, Indonesia \\ *widimulia27@gmail.com
}

\begin{abstract}
ABSTRAK
Penelitian ini bertujuan untuk mengetahui pengaruh komposisi partikel ampas tebu dan tempurung kelapa terhadap sifat fisis dan mekanis papan partikel. Dalam penelitian ini digunakan perbandingan komposisi bahan pengisi dengan jumlah perekat yang tetap. Variasi komposisi bahan yang digunakan partikel ampas tebu dan tempurung kelapa adalah 70:0\%, $50: 20 \%, 35: 35 \%, 20: 50 \%, 0: 70 \%$. Kadar perekat resin epoksi yang digunakan adalah $30 \%$. Ukuran partikel yang digunakan adalah lolos ayakan 100 mesh. Parameter yang diukur adalah densitas, kadar air, daya serap air, Modulus of Elasticity (MOE) dan Modulus of Rupture (MOR). Hasil uji sifat fisis diperoleh nilai densitas terendah 0,94 g/ $\mathrm{cm}^{3}$ pada komposisi 70\%:0\% dan densitas tertinggi $1,06 \mathrm{~g} / \mathrm{cm}^{3}$ pada komposisi $0 \%: 70 \%$. Nilai kadar air papan terendah 0,91\% pada komposisi 0\%:70\% dan nilai kadar air tertinggi 3,74\% pada komposisi 70\%:0\%. Nilai daya serap air terendah $17,11 \%$ pada komposisi 50\%:20\% sedangkan nilai daya serap air tertinggi $31,77 \%$ pada komposisi 35\%:35\%. Hasil uji sifat mekanis diperoleh nilai MOE terendah didapat sebesar 833,17 kg/ $\mathrm{cm}^{2}$ pada komposisi 70\%:0\% dan nilai MOE tertinggi sebesar 1960,75 kg/ $\mathrm{cm}^{2}$ pada komposisi 35\%:35\%. Nilai MOR terendah 487,88 kg/ $/ \mathrm{cm}^{2}$ pada komposisi 70\%:0\% sedangkan MOR tertinggi 1101,44 kg/cm pada komposisi 35\%:35\%. Hasil penelitian menunjukkan bahwa sifat fisis dan mekanis papan partikel yang didapatkan pada pengujian telah memenuhi standar mutu SNI 03-2105-2006 kecuali untuk pengujian densitas dan MOE. Berdasarkan persentase densitas papan partikel maka papan partikel yang dihasilkan termasuk jenis papan partikel berekerapatan tinggi.

Kata kunci: ampas tebu, tempurung kelapa, komposit, MOE, MOR, papan partikel.
\end{abstract}

ABSTRACT

The purpose of this research is to know the effect of composition bagasse and coconut shell particle to physical and mechanical properties of particle board. This research used composition ratio of materials and the fixed adhesives amount. The composition variation of the ingredients between bagasse and coconut shell that used were 70:0\%, 50:20\%, 35:35\%, 20:50\%, 0:70\%. The epoxy resin adhesive content that used was $30 \%$. The particle size that use in this research to pass the strain is 100 mesh. Parameters that researcher measured were density, moisture content, water absorption, Modulus of Elasticity (MOE) and Modulus of Rupture (MOR). The physical characteristics experiment result has showed that the lowest density is $0.94 \mathrm{~g} / \mathrm{cm}^{3}$ on ratio 70\%:0\% and the highest density is $1.06 \mathrm{~g} / \mathrm{cm}^{3}$ on ratio 0\%:70\%. The water content has showed that the lowest is $0.91 \%$ on ratio 0\%:70\% and the highest water content is $3.74 \%$ on ratio $70 \%: 0 \%$. The lowest water absorption is $17.11 \%$ on ratio 50\%:20\% while the highest water absorption is $31.77 \%$ on ratio $35 \%: 35 \%$. The result of mechanical characteristics that shown the lowest MOE value is $833.17 \mathrm{~kg} / \mathrm{cm}^{2}$ on ratio $70 \%: 0 \%$ and the highest value is $1960.75 \mathrm{~kg} / \mathrm{cm}^{2}$ on ratio $35 \%: 35 \%$. The lowest MOR value is $487.88 \mathrm{~kg} / \mathrm{cm}^{2}$ on ratio $70 \%: 0 \%$ while the highest MOR value is $1101.44 \mathrm{~kg} / \mathrm{cm}^{2}$ on ratio 35\%:35\%. The physical and mechanical characteristics of the particle board obtained in the test have qualified from the requirement of SNI 03-2105-2006 quality standard except for density and MOE test. Based on the percentage of particle board density, the result of particle board is including in to the type of high density particle board.

Keywords: bagasse, coconut shell, composite, MOE, MOR, particle board.

\section{PENDAHULUAN}

Kebutuhan manusia terhadap kayu sebagai bahan bangunan mengalami peningkatan yang signifikan. Bahan yang diperoleh dari kayu-kayu hutan mengakibatkan sumber daya hutan semakin berkurang. Kemampuan hutan untuk meproduksi kayu yang semakin menipis, menyebabkan permintaan kayu jauh lebih besar dari kayu yang tersedia, sehingga dicari 
alternatif bahan substitusi kayu yang memiliki kualitas lebih baik dibanding kayu dengan ketersediaan yang cukup melimpah (Armaya dkk., 2012). Salah satu cara untuk mengatasi pemenuhan kebutuhan akan keperluan kayu tersebut adalah dengan memanfaatkan limbahlimbah tumbuhan. Produksi papan buatan berupa papan partikel merupakan salah satu cara untuk memanfaatkan limbah-limbah tumbuhan yang tidak dimanfaatkan secara ekonomis.

Papan partikel adalah produk komposit yang dihasilkan dari pengempaan panas antara campuran partikel kayu atau bahan berlignoselulosa lainnya dengan perekat organik serta bahan perekat lainnya yang dibuat dengan cara pengempaan mendatar dengan dua lempeng datar (Roza dkk., 2015). Papan partikel mempunyai beberapa kelebihan dibandingkan dengan kayu seperti bebas mata kayu, tidak mudah pecah dan tidak mudah retak (Maloney, 1997). Pembuatan papan partikel berdasarkan pada pertimbangan ekonomis yaitu untuk memanfaatkan limbah dari berbagai jenis tumbuhan (Roza dkk., 2015).

Ampas tebu merupakan salah satu komoditi pertanian yang dihasilkan dari tebu. Ampas tebu yang dihasilkan dari pengolahan tebu dapat mencapai $40 \%$ dari berat tebu. Jadi, apabila per tahunnya dihasilkan 2,5 juta ton tebu maka dihasilkan sekitar 1 juta ton ampas tebu yang harus dioptimalkan (Mikael dkk., 2014). Potensi ampas tebu yang sangat besar ini harus dimanfaatkan seoptimal mungkin. Salah satunya adalah sebagai bahan baku pembuatan papan partikel.

Pembuatan papan partikel berbahan baku ampas tebu telah dilakukan oleh Iswanto., dkk (2009). Nilai Modulus of Elasticity (MOE) hasil penelitiannya berkisar antara 7548-8909 $\mathrm{kg} / \mathrm{cm}^{2}$. Standar SNI 03-2105-2006 dan JIS A 5908-2003 mensyaratkan nilai MOE minimal $20400 \mathrm{~kg} / \mathrm{cm}^{2}$. Mikael., dkk (2014) melakukan penelitian dengan menguji kualitas papan partikel dari campuran ampas tebu dan partikel mahoni dengan variasi kadar perekat phenol formaldehida. Penelitian tersebut memberikan hasil bahwa komposisi partikel ampas tebupartikel mahoni berpengaruh terhadap sifat mekanis yang dihasilkan. Perlakuan yang terbaik dari penelitian ini adalah komposisi partikel ampas tebu-partikel mahoni 50:20 dengan kadar perekat $30 \%$. Nilai MOE yang didapatkan berkisar antara $653,12-978,24 \mathrm{~kg} / \mathrm{cm}^{2}$ dan nilai Modulus of Rupture (MOR) dari hasil penelitian berkisar antara $51,88-106,23 \mathrm{~kg} / \mathrm{cm}^{2}$. Standar SNI 03-2105-2006 dan JIS A 5908-2003 mensyaratkan nilai MOR minimal $82 \mathrm{~kg} / \mathrm{cm}^{2}$. Upaya untuk meningkatkan sifat mekanis ampas tebu tersebut dapat dilakukan dengan cara menggabungkan partikel ampas tebu dengan partikel lain berkerapatan tinggi.

Irawati (2013) melakukan penelitian tentang pengaruh ukuran partikel tempurung kelapa sebagai pengisi komposit poliester tak jenuh terhadap sifat mekanis dan penyerapan air. Dari penelitian tersebut didapatkan bahwa sifat fisis (kerapatan, kadar air, daya serap air) papan partikel yang diuji telah memenuhi standar SNI 03-2105-2006. Penelitian tersebut menunjukkan bahwa pengisi serbuk tempurung kelapa ukuran 100 mesh mampu meningkatkan MOE sebesar $6083,47 \mathrm{~J} / \mathrm{m}^{3}$ dari poliester murni sebesar $3354,83 \mathrm{~J} / \mathrm{m}^{3}$. Penggabungan partikel ampas tebu dengan tempurung kelapa diharapkan akan memperbaiki sifat fisis dan mekanis papan partikel yang dihasilkan.

\section{METODE}

Bahan yang digunakan dalam penelitian ini adalah ampas tebu, tempurung kelapa dan resin epoksi. Ampas tebu dan tempurung kelapa yang digunakan dibersihkan dan dikeringkan, kemudian digrinding untuk memperkecil ukuran sehingga mempermudah proses penggilingan. Bahan yang sudah digiling kemudian diayak menggunakan ayakan 100 mesh dan hasil ayakan akan digunakan sebagai pengisi papan partikel.

Partikel yang diperoleh dicampur dalam wadah dan diaduk menggunakan mixer hingga homogen sesuai dengan komposisi masing-masing sampel dengan massa total yaitu $90 \mathrm{~g}$. Komposisi sampel divariasikan dengan perbandingan variasi komposisi ampas tebu : komposisi tempurung kelapa sebanyak 5 variasi yaitu 70:0\%, 50:20\%, 35:35\%, 20:50\% dan 0:70\% dengan komposisi perekat yang tetap 30\%. Sampel yang telah diaduk dituangkan dalam cetakan yang sudah dilapisi aluminium foil. Permukaan sampel diratakan dengan penutup yang tersedia pada cetakan dan ditekan menggunakan hot packing press dengan tekanan 2 ton pada suhu $150^{\circ} \mathrm{C}$ selama 10 menit. Sampel dikeringkan minimal selama 24 jam dan dilakukan uji sifat fisis dan uji mekanis. 
Pengujian sifat fisis dan mekanik papan partikel dilakukan berdasarkan standar SNI 032105-2006. Parameter uji sifat fisis yang akan dilakukan adalah densitas, kadar air, dan daya serap air. Sedangkan untuk uji sifat mekanis yang diuji adalah Modulus of Elasticity (MOE) dan Modulus of Rupture (MOR).

\section{HASIL DAN DISKUSI}

\subsection{Uji Sifat Fisis}

\subsubsection{Densitas}

Densitas merupakan salah satu sifat fisis yang menunjukkan perbandingan antara massa benda terhadap volumenya. Berdasarkan hasil pengukuran didapatkan hasil pengujian densitas seperti pada Gambar 1.

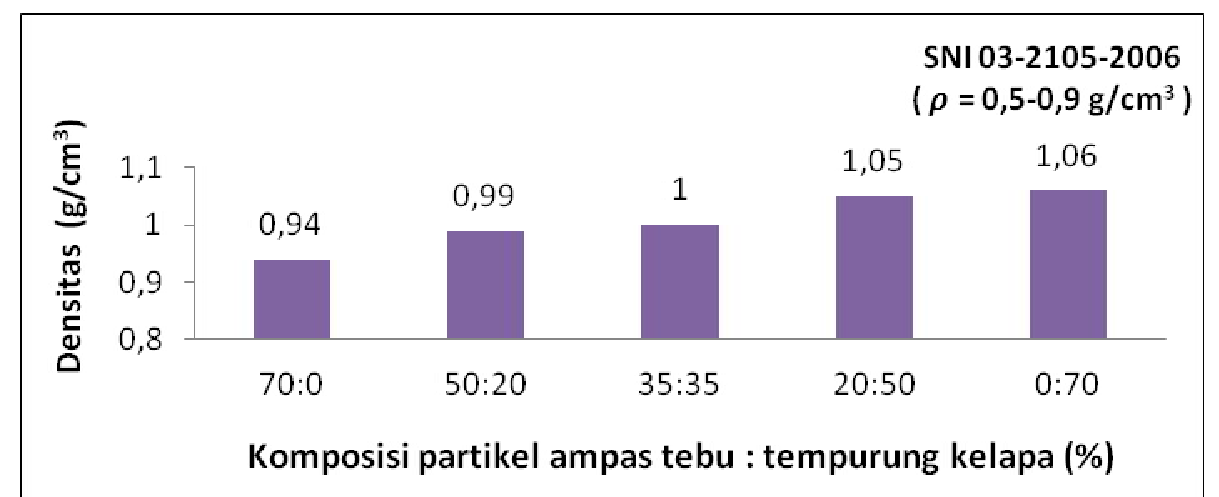

Gambar 1 Pengaruh komposisi ampas tebu dan tempurung kelapa terhadap densitas papan partikel

Gambar 1 menunjukkan nilai densitas papan partikel yang dihasilkan antara 0,94-1,06 $\mathrm{g} / \mathrm{cm}^{3}$. Densitas terendah papan partikel terdapat pada papan dengan komposisi filler 70\%:0\% dengan densitas $0,94 \mathrm{~g} / \mathrm{cm}^{3}$, sedangkan nilai densitas tertinggi papan partikel terdapat pada papan dengan komposisi filler 0\%:70\% dengan densitas $1,06 \mathrm{~g} / \mathrm{cm}^{3}$. Hasil penelitian menunjukkan bahwa penambahan komposisi partikel tempurung kelapa meningkatkan nilai densitas papan partikel yang dihasilkan. Nilai densitas papan partikel menurun menghampiri nilai yang ditetapkan SNI 03-2105-2006 $\left(0,5-0,9 \mathrm{~g} / \mathrm{cm}^{3}\right)$ seiring dengan bertambahnya komposisi partikel ampas tebu. Hal ini disebabkan karena berat jenis bahan baku yang digunakan, keberadaan berat jenis partikel tempurung kelapa $\left(0,75 \mathrm{~g} / \mathrm{cm}^{3}\right)$ lebih tinggi dibandingkan partikel ampas tebu $\left(0,12 \mathrm{~g} / \mathrm{cm}^{3}\right)$ memberikan peningkatan densitas papan partikel pada setiap penambahan komposisi tempurung kelapa.

Menurut Kelly (1977) dalam Muharam (1995) menyatakan bahwa faktor penting yang mempengaruhi nilai densitas papan partikel adalah berat jenis bahan baku. Selain itu, dapat dipengaruhi pula oleh kondisi proses produksi terutama proses pengempaan, pengeringan bahan baku, kadar perekat dan bahan tambahan lainnya. Standar SNI 03-2105-2006 menjelaskan bahwa denitas papan partikel yaitu $0,5-0,9 \mathrm{~g} / \mathrm{cm}^{3}$, maka densitas papan partikel yang didapat dalam penelitian ini melampaui standar mutu yang ditetapkan. Berdasarkan nilai densitas yang didapat untuk semua variasi komposisi papan partikel menunjukkan nilai densitas diatas 0,9 $\mathrm{g} / \mathrm{cm}^{3}$ yang dapat dikategorikan ke dalam papan partikel berkerapatan tinggi dimana nilai densitas papan partikel lebih dari $0,8 \mathrm{~g} / \mathrm{cm}^{3}$ (Maloney, 1997).

\subsubsection{Kadar Air}

Kadar air merupakan sifat fisis yang ditentukan setelah melalui proses pengovenan. Kadar air menunjukkan besarnya kandungan air yang terdapat pada papan partikel ketika berada dalam keadaan kesetimbangan dengan lingkungan sekitarnya. Kadar air dinyatakan dalam satuan persen. Berdasarkan hasil pengukuran didapatkan hasil pengujian kadar air seperti pada Gambar 2. 


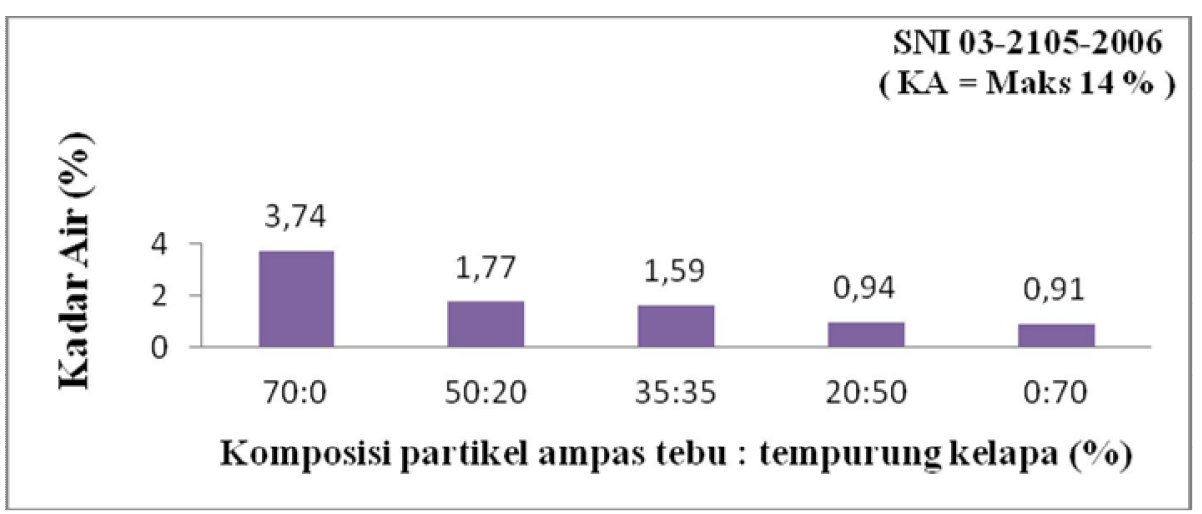

Gambar 2 Pengaruh komposisi ampas tebu dan tempurung kelapa terhadap kadar air papan partikel

Gambar 2 menunjukkan nilai kadar air papan partikel yang dihasilkan antara 0,913,74\%. Nilai kadar air terendah papan partikel terdapat pada papan dengan komposisi filler 0\%:70\% yaitu 0,91\%, sedangkan nilai kadar air tertinggi papan partikel terdapat pada papan dengan komposisi filler 70\%:0\% yaitu 3,74\%. Hasil penelitian memperlihatkan bahwa pengaruh komposisi partikel ampas tebu dan partikel tempurung kelapa terhadap kadar air dapat dilihat pada penambahan komposisi ampas tebu. Penambahan komposisi partikel ampas tebu menyebabkan meningkatnya nilai kadar air papan partikel. Hal ini dikarenakan oleh sifat higroskopis ampas tebu yang mudah menyerap air. Heygreen dan Bowyer (1996) menyatakan bahwa tingginya nilai kadar air disebabkan sifat papan partikel yang bersifat higroskopis yang sangat mudah menyerap air (Malau dkk., 2015).

Berdasarkan standar SNI 03-2105-2006 nilai kadar air papan partikel yang ditetapkan tidak melebihi $14 \%$. Nilai kadar air yang didapatkan untuk seluruh variasi komposisi papan partikel yang didapatkan pada penelitian ini memenuhi standar papan partikel. Berdasarkan data kadar air papan partikel di atas, komposisi papan partikel yang lebih baik dari seluruh variasi pengukuran adalah papan partikel dengan perbandingan komposisi 0\% (ampas tebu) berbanding $70 \%$ (tempurung kelapa) dengan kadar air $0,91 \%$.

\subsubsection{Daya Serap Air}

Daya serap air (DSA) merupakan kemampuan papan untuk menyerap air dalam jangka waktu tertentu. Pengujian daya serap air dilakukan setelah contoh uji direndam selama 24 jam. Hasil pengujian daya serap air ditunjukkan pada Gambar 3.

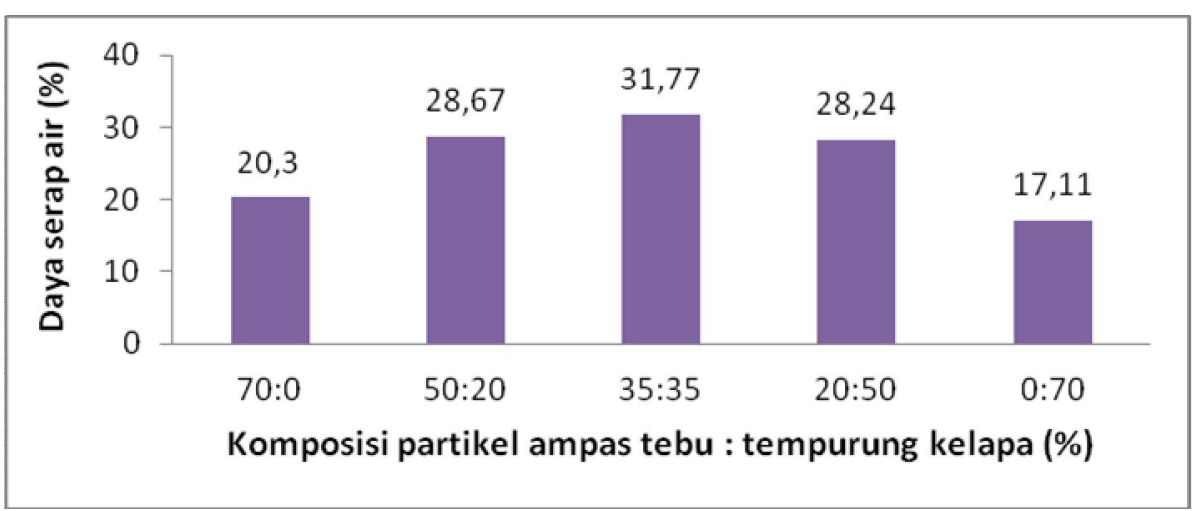

Gambar 3 Pengaruh komposisi ampas tebu dan tempurung kelapa terhadap daya serap air papan partikel

Gambar 3 memperlihatkan nilai daya serap air papan partikel setelah perendaman selama 24 jam antara 17,11-31,77\%. Nilai daya serap air terendah setelah perendaman 24 jam terdapat pada papan dengan komposisi filler 0\%:70\% yaitu 17,11\%, sedangkan nilai daya serap air tertinggi terdapat pada papan dengan komposisi filler 35\%:35\% yaitu 31,77\%. Hasil penelitian menunjukkan bahwa papan partikel dengan komposisi 35\%:35\% (komposisi partikel 
ampas tebu yang sama dengan komposisi tempurung kelapa) memiliki daya serap air yang besar dibandingkan komposisi lain. Hal ini diduga karena pada kondisi ini filler memiliki komposisi yang sama sehingga sifat higroskopis ampas tebu dan kandungan selulosa pada tempurung kelapa yang cukup besar menyebabkan papan memilki sifat fisis lebih homogen. Akibatnnya, papan mudah menyerap air. Komposisi partikel tempurung kelapa yang lebih besar dibandingkan komposisi partikel ampas tebu menyebabkan nilai daya serap air menurun. Hal ini disebabkan karena sedikitnya komposisi ampas tebu yang menyebabkan sifat higroskopis papan semakin rendah. Hal inilah yang membuat ikatan-ikatan yang telah terbentuk dalam papan partikel menjadi tidak mudah dirusak oleh air, sehingga daya serap airnya rendah.

Berdasarkan SNI 3-2105-2006 tidak mensyaratkan nilai daya serap air, akan tetapi uji nilai daya serap air ini perlu dilakukan karena uji ini dapat digunakan sebagai pertimbangan untuk menentukan penggunaan dari papan partikel ini, apakah layak digunakan pada eksterior atau hanya untuk interior. Berdasarkan hasil pengujian yang menunjukkan nilai daya serap air berkisar 17,11-31,77\%, maka papan partikel ini direkomendasikan untuk keperluan eksterior (Sutigno, 1994). Berdasarkan data daya serap air papan partikel di atas, komposisi papan partikel yang lebih baik dari seluruh variasi pengukuran adalah papan partikel dengan perbandingan komposisi 0\% (ampas tebu) berbanding 70\% (tempurung kelapa) dengan daya serap air $17,11 \%$.

\subsection{Sifat Mekanik}

\subsubsection{Modulus of Elasticity (MOE)}

Modulus of Elasticity (MOE) merupakan ukuran ketahanan papan partikel menahan beban sebelum patah (sampai batas proporsi). Dalam penelitian ini dilakukan pengujian menggunakan alat Universal Testing Machine (UTM) untuk memperoleh nilai MOE papan partikel yang dihasilkan. Hasil pengujian MOE papan partikel ditunjukkan pada Gambar 4.

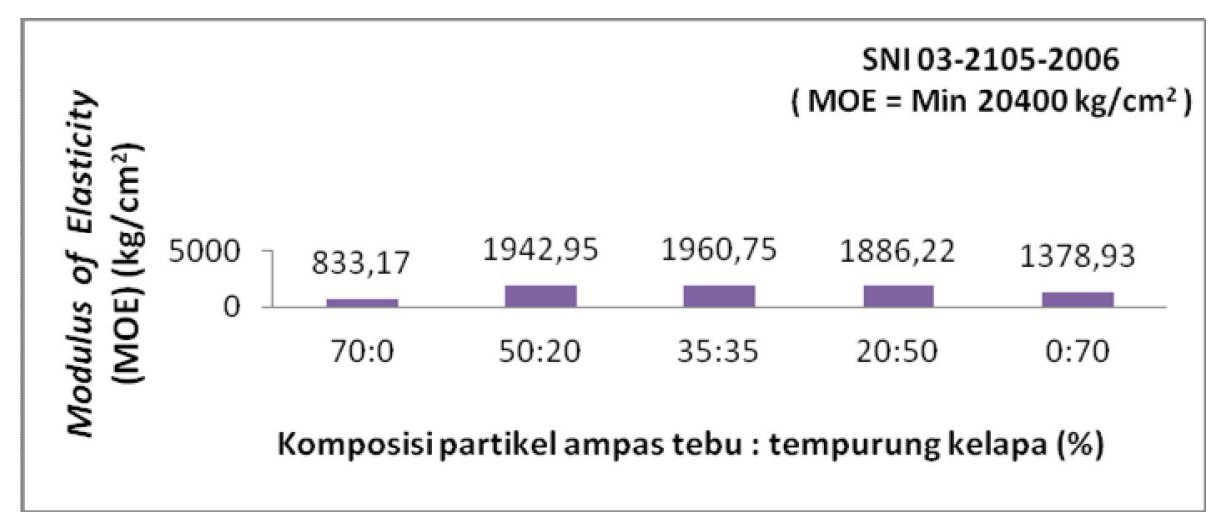

\footnotetext{
Gambar 4 Pengaruh komposisi ampas tebu dan tempurung kelapa terhadap MOE papan partikel
}

Gambar 4 menunjukkan bahwa nilai hasil pengujian MOE antara 833,17-1960,75 $\mathrm{kg} / \mathrm{cm}^{2}$. Nilai MOE terendah papan partikel terdapat pada papan dengan komposisi filler 70\%:0\% sebesar $833,17 \mathrm{~kg} / \mathrm{cm}^{2}$, sedangkan nilai MOE tertinggi terdapat pada papan dengan komposisi filler 35\%:35\% yaitu 1960,75 kg/ $\mathrm{cm}^{2}$. Hasil penelitian menunjukkan bahwa papan partikel dengan komposisi filler 35\%:35\% memiliki kondisi yang optimum dibandingkan komposisi lain. Hal ini disebabkan karena papan partikel dengan komposisi filler yang sama menyebabkan bentuk geometri papan yang terbuntuk lebih rapat. Akibatnya, sedikit pori-pori yang terbentuk karena komposisi yang sama saling mengikat. Ketika ditambahkan matriks (30\%) dengan komposisi yang hampir sama dengan komposisi filler, maka matriks akan mengisi pori-pori atau rongga dari filler tersebut. Ketika rongga pada partikel filler terisi penuh oleh matriks, hal inilah yang disebut kondisi optimum yang menyebabkan nilai MOE besar (Septiari dkk., 2014). Apabila komposisi filler tidak sama maka akan menyebabkan matriks tidak sepenuhnya mengisi pori-pori yang kosong. Akibatnya banyak partikel filler yang tidak saling terikat sehingga daya ikat papan partikel semakin rendah dan MOE papan partikel akan menurun. 
Berdasarkan hasil pengujian yang didapat untuk semua variasi komposisi filler belum memenuhi standar SNI 03-2105-2006 yang mensyaratkan nilai MOE papan partikel yaitu minimum $20.400 \mathrm{~kg} / \mathrm{cm}^{2}$. Hal ini diduga disebabkan karena masih banyaknya rongga udara pada papan partikel yang menyebabkan matriks tidak sepenuhnya mengisi ruang kosong pada filler sehingga daya ikat papan partikel semakin rendah. Berdasarkan data MOE papan partikel di atas, komposisi papan partikel yang lebih baik dari seluruh variasi pengukuran adalah papan partikel dengan perbandingan komposisi 35\% (ampas tebu) berbanding 35\% (tempurung kelapa) dengan nilai MOE $1960,75 \mathrm{~kg} / \mathrm{cm}^{2}$.

\subsubsection{Modulus of Rupture (MOR)}

Modulus of Rupture (MOR) papan partikel merupakan sifat mekanis yang menunjukkan kekuatan material dalam menahan beban yang bekerja terhadapnya sampai patah. Berdasarkan hasil pengukuran didapatkan hasil pengujian MOR seperti pada Gambar 5.

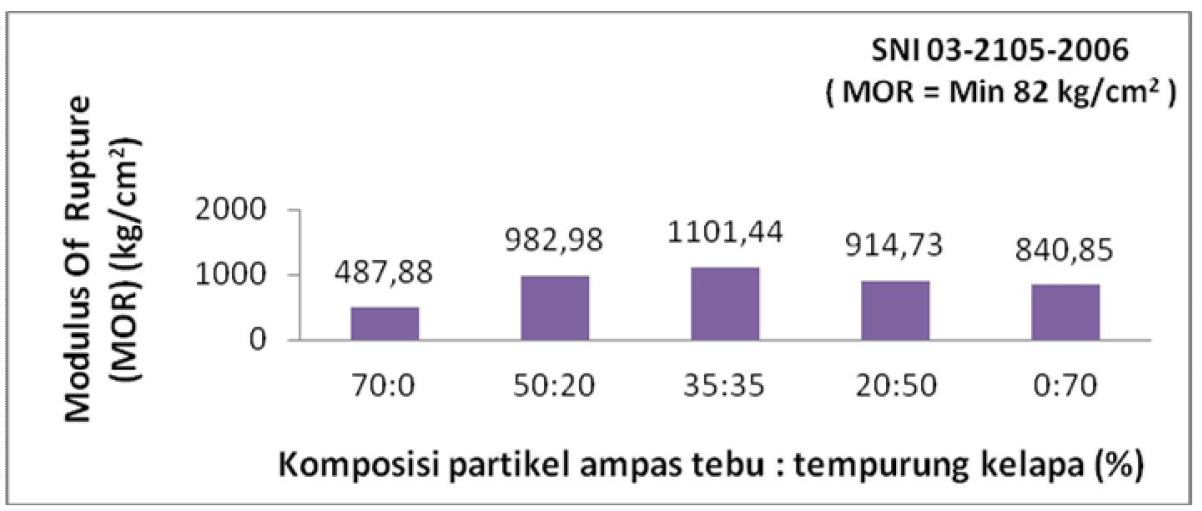

Gambar 5 Pengaruh komposisi ampas tebu dan tempurung kelapa terhadap MOR papan partikel

Gambar 5 memperlihatkan bahwa nilai hasil pengujian MOR antara 487,88-1101,44 $\mathrm{kg} / \mathrm{cm}^{2}$. Nilai MOR terendah papan partikel terdapat pada papan dengan komposisi filler 70\%:0\% yaitu 487,88 $\mathrm{kg} / \mathrm{cm}^{2}$ sedangkan nilai MOR tertinggi terdapat pada papan dengan komposisi filler 35\%:35\% yaitu 1101,44 kg/ $\mathrm{cm}^{2}$. Hasil penelitian menunjukkan bahwa papan partikel dengan komposisi filler yang sama akan memiliki nilai MOR yang besar dibandingkan dengan komposisi filler yang berbeda. Hal ini disebabkan karena komposisi filler yang sama (35\%:35\%) dan hampir sama dengan komposisi matriksnya (30\%) akan mudah menyatu (bercampur) sehingga mengakibatkan kuatnya ikatan filler dengan matriks. Sebaliknya, komposisi filler yang tidak sama akan menyebabkan ada filler yang berlebih dan tidak berinteraksi dengan filler yang lain. Keadaan ini menyebabkan daya ikat yang rendah sehingga nilai keteguhan patah papan menurun.

Berdasarkan standar SNI 03-2105-2006 nilai MOR papan partikel yang ditetapkan minimal $82 \mathrm{~kg} / \mathrm{cm}^{2}$. Nilai MOR yang didapatkan untuk seluruh variasi komposisi papan partikel yang didapatkan pada penelitian ini memenuhi standar papan partikel. Berdasarkan data nilai MOR papan partikel di atas, komposisi papan partikel yang lebih baik dari seluruh variasi pengukuran adalah papan partikel dengan perbandingan komposisi 35\% (ampas tebu) berbanding 35\% (tempurung kelapa) dengan nilai MOR 1101,44 kg/ $\mathrm{cm}^{2}$.

\section{KESIMPULAN}

Berdasarkan penelitian yang telah dilakukan dapat diambil kesimpulan bahwa hasil penelitian menunjukkan adanya pengaruh komposisi partikel ampas tebu dan tempurung kelapa terhadap sifat fisis dan mekanis papan partikel. Pada pengukuran sifat fisis didapatkan nilai densitas optimum sebesar $1,06 \mathrm{~g} / \mathrm{cm}^{3}$. Nilai kadar air optimum sebesar $0,91 \%$ dan nilai daya serap air optimum sebesar $17,11 \%$. Pada pengukuran sifat mekanis didapatkan niali MOE optimum sebesar 1960,75 $\mathrm{kg} / \mathrm{cm}^{2}$ dan nilai MOR optimum sebesar $1101,44 \mathrm{~kg} / \mathrm{cm}^{2}$. Hasil penelitian menunjukkan bahwa pengujian sifat fisis dan mekanis papan partikel telah memenuhi 
SNI 03-2105-2006 kecuali pengujian densitas dan MOE. Berdasarkan nilai densitas yang didapatkan, papan partikel ini digolongkan ke dalam papan partikel berkerapatan tinggi.

\section{DAFTAR PUSTAKA}

Armaya, R. Herawati, E. Sucipto, T., "Karakteristik Fisis dan Mekanis Papan Semen Bambu Hitam (Gigantochloa Atroviolacea Widjaja) dengan Dua Ukuran Partikel", Jurnal Kehutanan USU, 4, 9-15, (2012).

Haygreen, J.G. dan Bowyer, J.L., Pengantar Hasil Hutan dan Ilmu Kayu, Edisi ketiga (Gadjah Mada University, Yogyakarta, 1996), hal. 528-529.

Irawati, F., "Pengaruh Ukuran Serbuk Tempurung Kelapa Sebagai Pengisi Komposit Poliester Tak Jenuh Terhadap Sifat Mekanik dan Penyerapan Air", Jurnal Teknik Kimia USU, 2 , $31-37,(2013)$.

Iswanto, A.H., "Papan Partikel dari Ampas Tebu", Jurnal Ilmu dan Teknologi Kayu, 10, No.4, 103-111, (2009).

Malau, J.C. Sucipto, T. Iswanto A.H., "Kualitas Papan Partikel Batang Pisang Barangan Berdasarkan Variasi Kadar Perekat Phenol Formaldehida", Peronema Forestry Science Jurnal, 5, 32-38, (2015).

Maloney, T.M., Modren Particle board and Dry Proces Fiberboard Manufacturing (Miller Freman Inc, San Fransisco, 1997).

Mikael, I. Hartono, R. Sucipto, T., "Kualitas Papan Partikel Dari Campuran Ampas Tebu dan Partikel Mahoni Dengan Berbagai Variasi Kadar Perekat Phenol Formaldehida", Jurnal Kehutanan USU, 5, 1-8, (2014).

Muharam, A., "Pengaruh Ukuran Partikel dan Kerapatan Lembaran terhadap Sifat Fisis dan Mekanis Papan Partikel Ampas Tebu", Skripsi S1, Fakultas Teknologi Pertanian, Institut Pertanian Bogor, 1995.

Roza, D. Dirhamsyah, M. Nurhaida., "Sifat Fisik Dan Mekanik Papan Partikel dari Kayu Sengon (Paraserianthes Falcataria.L) dan Serbuk Sabut Kelapa (Cocos Nucifera.L)", Jurnal Hutan Lestari, 3, 374-382, (2015).

Septiari, P.W. Karyasa, W. Kartowarsono., "Pembuatan Papan Partikel dari Limbah Plastik Polyprophylene (PP) dan Tangkai Bambu", Jurnal Kimia Visvitalis Universitas Pendidikan Ganesha, 2, 117-126, (2014).

Standar Nasional Indonesia, Mutu Papan Partikel, SNI 03-2105-2006, (Badan Standar Nasional, Jakarta, 2006).

Sutigno, P., Teknologi Papan Partikel Datar (Pusat Penelitian dan Pengembangan Hasil Hutan dan Sosial Ekonomi Kehutanan, Bogor, 1994). 